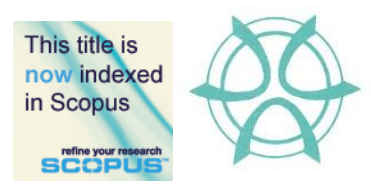

PLANNING MALAYSIA:

Journal of the Malaysian Institute of Planners

VOLUME 15 ISSUE 1 (2017), Page 201 - 208

\title{
PERCEPTION OF PARENTS AND GUARDIANS ON SAFE DISTANCE FOR CHILDREN TO TRAVEL TO PUBLIC AREAS
}

\author{
Mariana Mohamed Osman', Muhammad Faris Abdullah², Najihan \\ Khalid $^{3}$, Syahriah Bachok ${ }^{4}$, Nor Suzilawati Rabe ${ }^{5}$, Syafiee Shuid ${ }^{6}, \&$ \\ Zakiah Ponrahono $^{7}$ \\ ${ }^{1,2,3,4,5,6}$ Kuliyyah of Architecture and Environmental Design \\ INTERNATIONAL ISLAMIC UNIVERSITY MALAYSIA \\ ${ }^{7}$ Faculty of Environmental Studies \\ UNIVERSITI PUTRA MALAYSIA
}

\begin{abstract}
Children safety is of utmost important. Children are susceptible to safety risk while traveling to public areas such as schools, parks and bus stops. Perception of parents and guardians on the safety of their children determines their decision whether or not to allow their children to travel to public areas and how. This study looks at the perception of parents and guardians on the safe distance for children to travel to public areas. 4,500 respondents were surveyed. It was found that parents and guardians perception of safe distance is heavily influenced by distance and children's age factors.
\end{abstract}

Keyword: Safe distance, children, public areas

Date Received: $30^{\text {th }}$ April 2016

Date of Acceptance: $30^{\text {th }}$ October 2016 
Mariana, Muhammad Faris, Najihan, Syahriah, Nor Suzilawati, Syafiee, \& Zakiah

Perception of Parents and Guardians on Safe Distance for Children to Travel to Public Areas

\section{INTRODUCTION}

Increasing incidence of crime against children has posed a challenge to parents and families in ensuring the safety of their children (Al-Dawamy \& Sulaiman, 2010). Parents tend to focus on the welfare and safety of their children and most parents tend to ensure that their children are within their view when at public places. Knowledge of the suitable safe distance is crucial to ensure safety of children, especially when the children are to travel to public areas. Thus, the aim of this research is to study parents and guardians perception on the safe distance for children to travel to public areas such as schools, shopping mall, community facilities, bus stations, parks and others.

\section{Background of the Study}

Knowledge on safe distance is crucial to community in order to prevent unwanted incidents involving children from happening due to the negligence of parents in public areas. Public areas are areas that include residential area, schools, parks, shopping malls and other public places. According to Mammen, Buliung \& Lay (2012) and Oluyomi et al. (2014), distance is one of the factors that influences the element of safety among children. Their studies found that the closer the distance between school and home, the higher the perception of safety among parents. Other factors such as the security system in school, the type of development surrounding the school and the school condition also influence the perceived safety of children among parents (Mammen, Buliung \& Lay, 2012; Oluyomi et al., 2014). McDonald (2008) suggests that a typical walking rate for school-aged children is about 2.7 miles per hour (or 1.35 miles per 30 minuteperiod). Therefore, most children will probably not walk farther than 1.35 to/from school.

Crime against children is a widely discussed issue among the public. This is not unwarranted since researchers have found that crime against children are increasing yearly (Al-Dawamy \& Sulaiman, 2010). This, to an extent has affected parents in determining where their children can go and how to go there. In the United States, according to Evers et al. (2014), walking rates to school among children remain low because parents are concerned for their children safety. Safety in this case is not limited to only crime, but also road safety (Fatimah \& Osman, 1997).

In Malaysia, Child Act 2001 (Act 611) was enacted with the aim to preserve and protect the social and physical rights of children. Act 611 highlights the responsibility of parents or guardians to protect the well-being of children. Parents or guardians are considered guilty and subjected to criminal offence if these responsibilities are ignored (Act 611; Mohd Yussof \& Tahir, 2005). 


\section{METHODOLOGY}

This study adopted questionnaire survey method for primary data collection. The questionnaire survey form was made up of two sections to obtain information regarding respondents' profile and their perception of safe distance. Using the from, enumerators surveyed 4,500 respondents in the Klang Valley region. The areas selected fall within the administrative boundary of Kuala Lumpur City Hall (1,000 respondents), Shah Alam City Council (1,000 respondents) Petaling Jaya City Council (500 respondents), Subang Jaya Municipal Council (500 respondents), Ampang Jaya Municipal Council (500 respondents), Klang Municipal Council (500 respondents) and Selayang Municipal Council (500 respondents). The targeted respondents were those aged at least 18 years old and have at least a child or a relative who are still schooling either at preschool, primary school or secondary school level. Data obtained through the survey was keyed in into SPSS software and analysed using both descriptive and inferential analyses.

\section{ANALYSIS AND FINDINGS}

\section{Respondents' Profile}

Table 1 below shows the profile of the respondents. The majority of the respondents $(63 \%)$ were those aged between 18 to 39 years old. In terms of race, $74 \%$ of the respondents were Malay. The majority of the respondents attained diploma level in education and over $85 \%$ were in employment. The average household size was 4 .

Table 1 Respondents' Profile

\begin{tabular}{lllcc}
\hline $\begin{array}{l}\text { Respondents' } \\
\text { profile }\end{array}$ & Category & & Frequency & $\begin{array}{c}\text { Percentage } \\
(\%)\end{array}$ \\
\hline Age & Youth & $: 18-39$ years old & 2,839 & 63.1 \\
& Adult & $: 40-60$ years old & 1,628 & 36.2 \\
& Retired & $: 60$ years old & 33 & 0.7 \\
\hline Sex & Male & & 2,044 & 45.4 \\
& Female & & 2,456 & 54.6 \\
\hline Race & Malay & & 3,344 & 74.3 \\
& Chinese & & 699 & 15.5 \\
& Indian & & 430 & 9.6 \\
& Others & & 27 & 0.6 \\
\hline Education & Primary & : Primary School & 88 & 2.0 \\
& Middle & : Secondary School & 899 & 20.0 \\
& Higher & : Certificate & 458 & 10.2 \\
& & : Diploma & 995 & 22.1 \\
& & : Degree & 1,750 & 38.9 \\
& & : Master & 272 & 6.0 \\
\hline
\end{tabular}


Mariana, Muhammad Faris, Najihan, Syahriah, Nor Suzilawati, Syafiee, \& Zakiah

Perception of Parents and Guardians on Safe Distance for Children to Travel to Public Areas

\begin{tabular}{|c|c|c|c|c|}
\hline & & $: \mathrm{PhD}$ & 38 & 0.8 \\
\hline \multirow{3}{*}{$\begin{array}{l}\text { Marital } \\
\text { status }\end{array}$} & Single & & 265 & 5.9 \\
\hline & Married & & 4,119 & 91.5 \\
\hline & Divorced & & 116 & 2.6 \\
\hline \multirow[t]{8}{*}{ Occupation } & \multirow[t]{3}{*}{ Employed } & : Executive, & 1,553 & 34.5 \\
\hline & & Professional & 1,777 & 39.5 \\
\hline & & : Admin & 465 & 10.3 \\
\hline & \multirow[t]{5}{*}{ Unemployed } & Management & 181 & 4.0 \\
\hline & & : Business & 477 & 10.6 \\
\hline & & : Full-time Student & 47 & 1.0 \\
\hline & & : Housewives & & \\
\hline & & : Retired & & \\
\hline \multirow{7}{*}{$\begin{array}{l}\text { Household } \\
\text { income }\end{array}$} & \multicolumn{2}{|c|}{ RM 1,000 - RM 1,999 } & 264 & 5.9 \\
\hline & \multicolumn{2}{|c|}{ RM 2,000 - RM 2,999 } & 609 & 13.5 \\
\hline & \multicolumn{2}{|c|}{ RM 3,000 - RM 3,999 } & 1,042 & 23.2 \\
\hline & \multicolumn{2}{|c|}{ RM 4,000 - RM 4,999 } & 844 & 18.8 \\
\hline & \multicolumn{2}{|c|}{ RM 5,000 - RM 5,999 } & 670 & 14.9 \\
\hline & \multicolumn{2}{|c|}{ RM 6,000 - RM 6,999 } & 374 & 8.3 \\
\hline & \multicolumn{2}{|l|}{$>\mathrm{RM} 7,000$} & 697 & 15.5 \\
\hline \multirow{4}{*}{$\begin{array}{l}\text { Household } \\
\text { size }\end{array}$} & \multicolumn{2}{|l|}{$<3$} & 1,340 & 29.8 \\
\hline & \multicolumn{2}{|l|}{$4-6$} & 2,767 & 61.5 \\
\hline & \multicolumn{2}{|l|}{$7-9$} & 352 & 7.8 \\
\hline & \multicolumn{2}{|l|}{$>10$} & 41 & 0.9 \\
\hline
\end{tabular}

Source: Questionnaire Survey, 2015

Table 2 below shows the number of children or relatives of respondents by gender. The highest number of respondents $(61 \%)$ has at least one male child or relative who are attending school. Meanwhile, $51 \%$ of the respondents have at least one female child or relative who are still schooling.

Table 2 Number of Children/Relatives Still Schooling by Gender

\begin{tabular}{|c|c|c|c|c|c|c|c|c|c|c|}
\hline \multirow{2}{*}{\multicolumn{2}{|c|}{ Gender }} & \multicolumn{7}{|c|}{ Female child/relative (nos) } & \multirow{2}{*}{ Total } & \multirow{2}{*}{$\%$} \\
\hline & & 0 & 1 & 2 & 3 & 4 & 5 & 6 & & \\
\hline \multirow{7}{*}{$\begin{array}{l}\text { Male } \\
\text { child/ } \\
\text { relativ } \\
\text { e (nos) }\end{array}$} & 0 & 0 & 896 & 165 & 69 & 10 & 4 & 10 & 1,154 & 25.6 \\
\hline & 1 & 1,343 & 1,229 & 126 & 26 & 13 & 4 & 1 & 2,742 & 60.9 \\
\hline & 2 & 186 & 126 & 97 & 18 & 7 & 1 & 1 & 436 & 9.7 \\
\hline & 3 & 52 & 28 & 28 & 8 & 3 & 1 & 0 & 120 & 2.7 \\
\hline & 4 & 19 & 6 & 5 & 2 & 2 & 0 & 0 & 34 & 0.8 \\
\hline & 5 & 9 & 0 & 0 & 0 & 0 & 0 & 0 & 9 & 0.2 \\
\hline & 6 & 0 & 2 & 2 & 1 & 0 & 0 & 0 & 5 & 0.1 \\
\hline \multicolumn{2}{|c|}{ Total } & 1,609 & 2,287 & 423 & 124 & 35 & 10 & 12 & 4,500 & 100.0 \\
\hline \multicolumn{2}{|c|}{$\%$} & 35.8 & 50.8 & 9.4 & 2.8 & 0.8 & 0.2 & 0.3 & 100.0 & \\
\hline
\end{tabular}


Children Mode of Transportation to Public Area

Table 3 shows the children mode of transportation in going to public area. Over $80 \%$ of respondents stated that their children or relatives travel to public area in motorised transport. Of this, $67 \%$ travel using private transportation and $14 \%$ travel using public transportation. Only $11 \%$ walk, and $9 \%$ cycle, to public area.

Table 3 Children Mode of Transportation to Public Area

\begin{tabular}{|l|l|c|c|}
\hline Vehicle type & Transportation mode & Frequency & \% \\
\hline \multirow{2}{*}{ Motorised } & Private & 3,002 & 66.7 \\
\cline { 2 - 4 } & Public & 621 & 13.8 \\
\hline \multirow{2}{*}{ Non-motorised } & Sub-total & 3,623 & 80.5 \\
\cline { 2 - 4 } & Walking & 476 & 10.6 \\
\cline { 2 - 4 } & Cycling & 401 & 8.9 \\
\hline \multicolumn{2}{|c|}{ Sub-total } & 877 & 19.5 \\
\hline
\end{tabular}

\section{Respondent Perception of Safe Distance}

Respondents were asked on the distance they perceived as safe for their children to travel to public area. $49 \%$ of the respondents felt that it was safe for children to walk within 100 metres to public area (Table 4). Meanwhile, $31 \%$ perceived 400 metres as the safe distance for children to walk to public area and $20 \%$ felt that it was still safe for children to walk 1 kilometre to public area. This indicates that the farther the children have to travel to public area, the less safe it was perceived by the respondents.

Table 4 Perceived safe distance

\begin{tabular}{lcc}
\hline Statement & Frequency & $\begin{array}{c}\text { Percentage } \\
(\%)\end{array}$ \\
\hline $\begin{array}{l}\text { Safe distance is to walk within 100 meters to the } \\
\text { public area }\end{array}$ & 2,193 & 48.7 \\
$\begin{array}{l}\text { Safe distance is to walk within 400 meters to the } \\
\text { public area }\end{array}$ & 1,397 & 31.0 \\
$\begin{array}{l}\text { Safe distance is to walk within about 1 km to the } \\
\text { public area }\end{array}$ & 910 & 20.2 \\
\hline Total & $\mathbf{4 , 5 0 0}$ & $\mathbf{1 0 0 . 0}$ \\
\hline $\begin{array}{l}\text { Source: Questionnaire Survey, 2015 } \\
\end{array}$
\end{tabular}

A cross-tabulation between results from Table 4 and Table 5 shows that despite perceiving that 100 metres is a safe distance for children to travel to public areas, many of the respondents still transport their children to those areas in private vehicle (Table 5). In fact, for each category of safe distance (i.e. $100 \mathrm{~m}$, $400 \mathrm{~m}$ and $1 \mathrm{~km}$ ), private vehicle was the highest mode of transportation chose by 
Mariana, Muhammad Faris, Najihan, Syahriah, Nor Suzilawati, Syafiee, \& Zakiah

Perception of Parents and Guardians on Safe Distance for Children to Travel to Public Areas

the respondents. This reflects that respondents perceived traveling by private vehicles as safer than other modes of transportation.

Table 5 Respondent Perception on Safe Distance for Children and Mode of

Transportation

\begin{tabular}{lcccc}
\hline Mode of & \multicolumn{2}{c}{ Perception of respondents on safe distance } & Total \\
\cline { 2 - 4 } transportation & $\begin{array}{c}\text { 100m walking to } \\
\text { public area }\end{array}$ & $\begin{array}{c}\text { 400m walking to } \\
\text { public area }\end{array}$ & $\begin{array}{c}1 \text { km walking to } \\
\text { public area }\end{array}$ & \\
\hline Walking & 203 & 156 & 117 & $\mathbf{4 7 6}$ \\
& $(4.5 \%)$ & $(3.5 \%)$ & $(2.6 \%)$ & $(\mathbf{1 0 . 6 \% )}$ \\
\hline Riding bicycle & 140 & 154 & 107 & $\mathbf{4 0 1}$ \\
& $(3.1 \%)$ & $(3.4 \%)$ & $(2.4 \%)$ & $\mathbf{( 8 . 9 \% )}$ \\
\hline Private vehicle & 1,604 & 864 & 534 & $\mathbf{3 , 0 0 2}$ \\
& $(35.6 \%)$ & $(19.2 \%)$ & $(11.9 \%)$ & $(\mathbf{6 6 . 7 \%})$ \\
\hline Public & 246 & 223 & 152 & $\mathbf{6 2 1}$ \\
transport & $(5.5 \%)$ & $(5.0 \%)$ & $(3.4 \%)$ & $\mathbf{( 1 3 . 8 \% )}$ \\
\hline Total & $\mathbf{2 , 1 9 3}$ & $\mathbf{1 , 3 9 7}$ & $\mathbf{9 1 0}$ & $\mathbf{4 , 5 0 0}$ \\
& $\mathbf{( 4 8 . 7 \% )}$ & $\mathbf{( 3 1 \% )}$ & $\mathbf{( 2 0 . 2 \% )}$ & $\mathbf{( 1 0 0 . 0 \% )}$ \\
\hline
\end{tabular}

Source: Questionnaire Survey, 2015

Chi-square analysis (Table 6) shows that there is a significant relationship between the respondents' perceptions of the safe distance for children to travel to public area with the mode of transportation they travelled in. Respondents tend to perceived that using private vehicle would be safer as compared to using public transport, cycling or walking.

Table 6 Chi-Square Analysis on Respondent Perception on Safety Distance with Mode of Transportation

\begin{tabular}{lccc}
\hline & Value & df & Asymp. Sig. (2-sided) \\
\hline Pearson Chi-Square & $87.774^{\mathrm{a}}$ & 6 & .000 \\
Likelihood Ratio & 88.350 & 6 & .000 \\
Linear-by-Linear Association & 5.590 & 1 & .018 \\
\hline N of Valid Cases & 4500 & \\
\hline a. 0 cells (.0\%) have expected count less than 5. The minimum expected count is 81.09.
\end{tabular}

\section{Determinants of Safe Distance}

A review of the literatures has identified six factors that commonly influence parents and guardians in determining the safe distance their children are allowed to travel to. These factors are age of the child, gender of the child, distance to the destination (whether near or far), the company of the child (whether the child travels alone or with company), time (whether day or night) and familiarity of the destination. In this study, respondents were asked to rank these factors in order to 
PLANNING MALAYSIA

Journal of the Malaysia Institute of Planners (2017)

determine which factors influenced them most in deciding how far is safe for their children to travel to public areas.

Table 7 Respondents' perception on factors determining the safe distance

\begin{tabular}{|c|c|c|c|c|c|c|c|c|}
\hline Factors & Rank 1 & Rank 2 & Rank 3 & Rank 4 & Rank 5 & Rank 6 & $\begin{array}{l}\text { Mean } \\
\text { score }\end{array}$ & $\begin{array}{c}\text { Priority } \\
\text { order }\end{array}$ \\
\hline Age & $\begin{array}{c}1,391 \\
(30.9 \%)\end{array}$ & $\begin{array}{c}1,252 \\
(27.8 \%)\end{array}$ & $\begin{array}{c}608 \\
(13.5 \%)\end{array}$ & $\begin{array}{c}418 \\
(9.3 \%)\end{array}$ & $\begin{array}{c}383 \\
(8.5 \%)\end{array}$ & $\begin{array}{c}448 \\
(10 \%)\end{array}$ & 2.67 & 1 \\
\hline $\begin{array}{l}\text { Sex } \\
\text { (Male/ } \\
\text { Female) }\end{array}$ & $\begin{array}{c}1,039 \\
(23.1 \%)\end{array}$ & $\begin{array}{c}1,062 \\
(23.6 \%)\end{array}$ & $\begin{array}{c}754 \\
(16.8 \%)\end{array}$ & $\begin{array}{c}545 \\
(12.1 \%)\end{array}$ & $\begin{array}{c}577 \\
(12.8 \%)\end{array}$ & $\begin{array}{c}523 \\
(11.6 \%)\end{array}$ & 3.03 & 2 \\
\hline $\begin{array}{l}\text { Distance } \\
\text { (Near/Far) }\end{array}$ & $\begin{array}{c}585 \\
(13 \%)\end{array}$ & $\begin{array}{c}703 \\
(15.6 \%)\end{array}$ & $\begin{array}{l}1,037 \\
(23 \%)\end{array}$ & $\begin{array}{c}1,020 \\
(22.7 \%)\end{array}$ & $\begin{array}{c}810 \\
(18 \%)\end{array}$ & $\begin{array}{c}345 \\
(7.7 \%)\end{array}$ & 3.40 & 3 \\
\hline $\begin{array}{l}\text { Chile } \\
\text { condition } \\
\text { (Alone/ } \\
\text { With }\end{array}$ & $\begin{array}{c}865 \\
(19.2 \%)\end{array}$ & $\begin{array}{c}687 \\
(15.3 \%)\end{array}$ & $\begin{array}{c}802 \\
(17.8 \%)\end{array}$ & $\begin{array}{c}740 \\
(16.4 \%)\end{array}$ & $\begin{array}{c}626 \\
(13.9 \%)\end{array}$ & $\begin{array}{c}780 \\
(17.3 \%)\end{array}$ & 3.43 & 4 \\
\hline Company) & & & & & & & & \\
\hline $\begin{array}{l}\text { Time } \\
\text { (Night/Day) }\end{array}$ & $\begin{array}{c}366 \\
(8.1 \%)\end{array}$ & $\begin{array}{c}542 \\
(12 \%)\end{array}$ & $\begin{array}{c}882 \\
(9.6 \%)\end{array}$ & $\begin{array}{c}1,139 \\
(25.3 \%)\end{array}$ & $\begin{array}{c}1,146 \\
(25.5 \%)\end{array}$ & $\begin{array}{c}425 \\
(9.4 \%)\end{array}$ & 3.76 & 5 \\
\hline $\begin{array}{l}\text { Destination } \\
\text { (Familiar/Unf } \\
\text { amiliar) }\end{array}$ & $\begin{array}{c}249 \\
(5.5 \%)\end{array}$ & $\begin{array}{c}259 \\
(5.8 \%)\end{array}$ & $\begin{array}{c}418 \\
(9.3 \%)\end{array}$ & $\begin{array}{c}647 \\
(14.4 \%)\end{array}$ & $\begin{array}{c}958 \\
(21.3 \%)\end{array}$ & $\begin{array}{c}1,969 \\
(43.8 \%)\end{array}$ & 4.71 & 6 \\
\hline Total & $\begin{array}{l}4,500 \\
(100) \\
\end{array}$ & $\begin{array}{l}4,500 \\
(100) \\
\end{array}$ & $\begin{array}{l}4,500 \\
(100) \\
\end{array}$ & $\begin{array}{l}4,500 \\
(100) \\
\end{array}$ & $\begin{array}{l}4,500 \\
(100) \\
\end{array}$ & $\begin{array}{l}4,500 \\
(100) \\
\end{array}$ & & \\
\hline
\end{tabular}

Based on the results shown in Table 7, the most important factors perceived by the respondents in determining the safe distance for children to travel to public areas was age of the child. Over 30\% of the respondents ranked age as the most important factor (i.e. Rank 1). Meanwhile, familiarity with the destination was perceived as the least important factor with only $6 \%$ of the respondents ranked this factor as the most important. Mean score analysis also portrays the same result. Age of the child was the highest priority factor, with a mean score of 2.67. Familiarity with destination was the lowest priority factor with a mean score of 4.71 .

\section{Public perception on the importance of safe distance}

Respondents were also asked to rank the importance of safe distance for children to travel to public areas. Based on ranking, ensuring safety of children in public places was the most important reason to the respondents. It received Rank 1 from over $40 \%$ of the respondents (Table 8 ). Similarly, based on mean score analysis, ensuring safety of children in public places was also the highest priority, with a mean score of 2.06. This is followed by, in order of importance, reducing crime rate, ensuring access to public places, reducing road accidents and contributing towards safe city. 
Mariana, Muhammad Faris, Najihan, Syahriah, Nor Suzilawati, Syafiee, \& Zakiah

Perception of Parents and Guardians on Safe Distance for Children to Travel to Public Areas

Table 8 Public Perception on the Importance of Safe Distance

\begin{tabular}{|c|c|c|c|c|c|c|c|}
\hline Statements & Rank 1 & Rank 2 & Rank 3 & Rank 4 & Rank 5 & $\begin{array}{c}\text { Average } \\
\text { score }\end{array}$ & $\begin{array}{c}\text { Priority } \\
\text { order }\end{array}$ \\
\hline $\begin{array}{l}\text { Ensuring the safety of } \\
\text { children in public places. }\end{array}$ & $\begin{array}{c}1,956 \\
(43.5 \%)\end{array}$ & $\begin{array}{c}1,254 \\
(27.9 \%)\end{array}$ & $\begin{array}{c}657 \\
(14.6 \%)\end{array}$ & $\begin{array}{c}316 \\
(7 \%)\end{array}$ & $\begin{array}{c}317 \\
(7 \%)\end{array}$ & 2.06 & 1 \\
\hline Reducing crime rate. & $\begin{array}{c}1,143 \\
(25.4 \%)\end{array}$ & $\begin{array}{c}1,295 \\
(28.8 \%)\end{array}$ & $\begin{array}{c}1,188 \\
(26.4 \%)\end{array}$ & $\begin{array}{l}538 \\
(12 \%)\end{array}$ & $\begin{array}{c}336 \\
(7.5 \%)\end{array}$ & 2.47 & 2 \\
\hline $\begin{array}{l}\text { Ensuring accessibility to } \\
\text { public facilities. }\end{array}$ & $\begin{array}{c}905 \\
(20.1 \%)\end{array}$ & $\begin{array}{c}963 \\
(21.4 \%)\end{array}$ & $\begin{array}{c}896 \\
(19.9 \%)\end{array}$ & $\begin{array}{c}895 \\
(19.9 \%)\end{array}$ & $\begin{array}{c}841 \\
(18.7 \%)\end{array}$ & 2.96 & 3 \\
\hline Reducing road accidents. & $\begin{array}{c}222 \\
(4.9 \%)\end{array}$ & $\begin{array}{c}568 \\
(12.6 \%)\end{array}$ & $\begin{array}{c}1,132 \\
(25.2 \%)\end{array}$ & $\begin{array}{c}1,637 \\
(36.4 \%)\end{array}$ & $\begin{array}{c}941 \\
(20.9 \%)\end{array}$ & 3.56 & 4 \\
\hline $\begin{array}{l}\text { Assisting in creating a safe } \\
\text { city. }\end{array}$ & $\begin{array}{c}274 \\
(6.1 \%)\end{array}$ & $\begin{array}{c}420 \\
(9.3 \%)\end{array}$ & $\begin{array}{c}627 \\
(13.9 \%)\end{array}$ & $\begin{array}{c}1,114 \\
(24.8 \%)\end{array}$ & $\begin{array}{c}2,065 \\
(45.9 \%)\end{array}$ & 3.95 & 5 \\
\hline Total & $\begin{array}{c}4,500 \\
(100 \%)\end{array}$ & $\begin{array}{c}4,500 \\
(100 \%)\end{array}$ & $\begin{array}{c}4,500 \\
(100 \%)\end{array}$ & $\begin{array}{c}4,500 \\
(100 \%)\end{array}$ & $\begin{array}{c}4,500 \\
(100 \%)\end{array}$ & & \\
\hline
\end{tabular}

\section{CONCLUSION}

This study was successful in identifying the perception of parents and guardians on safe distance for their children to travel to public areas. It was found that majority of the respondents perceived that it was safest for children to walk 100 metres to public areas. However, this is heavily influenced by the age of the children. Respondents also perceived that safe distance is important in order to ensure safety of children in public areas.

\section{REFERENCES}

Akta Kanak-Kanak (2001)

Al-Dawamy, A. R., \& Sulaiman, S. N. H. (2001) Persepsi pelajar tentang kejadian jenayah terhadap kanak-kanak. Universiti Teknologi Malaysia.

Evers, C., Boles, S., Johnson-Sheltona, D., Schlossberg, M., \& Richey, D. (2014). Parent safety perceptions of child walking routes. Journal of Transport \& Health, 1, 108115.

Fatimah, M., \& Osman, A. (1997). The risk of road traffic accidents among primary school children in Kuala Terengganu. Medical Journal Malaysia, 52(4), 402-408.

Mammen, G., Faulkner, G., Buliung, R., \& Lay, J. (2012). Understanding the drive to escort: a cross-sectional analysis examining parental attitudes towards children's school travel and independent mobility. BMC Public Health, 12, 862. DOI: 10.1186/1471-2458-12862.

Mohd Yussof, J. Z., \& Tahir, Z. (2005). Akta Kanak-Kanak 2001: penguatkuasaan semula tugas dan tanggungjawab ibu bapa atau penjaga? Journal of Malaysian and Comparative Law, 32(1).

McDonald N. C. (2008). Children's mode choice for the school trip: the role of distance and school location in walking to school. Transportation, 35(1), 23-35.

Oluyomi, A. O., Lee, C., Nehme, N., Dowdy, D., Ory, M. G., \& Hoelscher, D. M. (2014). Parental safety and concerns and active school commute: correlates across multiple domains in the home-to-school journey. International Journal of Behavioral Nutrition and Physical Activity, 11(1), 32. DOI: 10.1186/1479-5868-11-32. 